skin, it would appear that depilatories are bound to affect the skin keratin. For the purpose of depilation, Dr. Moynahan said that he prefers the method of electrolysis, although this method is impracticable for axillary hair removal in women. After briefly referring to cases of oil dermatitis caused by the use of 'brilliantines', he interpolated some comments on keratoplastics and then referred to the merits and defects of barrier (protective) creams. His concluding remarks dealt with the indiscriminate use of disinfectants, which can easily intensify skin irritation, and with the potential dermatitis-provoking action of highly rosined soaps.

\section{COPENHAGEN BIOLOGICAL CONFERENCE}

$\mathrm{R}$

ECENT developments and present trends in cellular biology, physiology and chemistry formed the subject of a joint Danish-British conference held during April 30-May 2 at the Danmarks Farmaceutiske Hojskole in Copenhagen. At the invitation of Danish biologists and the University of Copenhagen, a group of research workers from Great Britain as well as several Danish scientific workers reported on the progress of their own researches, dealing with a variety of topics, which were chiefly, though not exclusively, concerned with the correlation of cell composition with specific cell functions such as growth, division and survival.

The opening session, at which the chair was taken by Dr. A. F. Hughes, began with Prof. H. G. Callan's account of his studies on the amphibian oocyte nuclei; he was followed by Dr. W. S. Bullough, who spoke on the effect of cestrogenic hormones on carbohydrate metabolism and mitosis in mouse ear epidermis; and Dr. M. Webb on the influence of certain extraneous agents, chiefly magnesium, on cell division in bacterial cultures. Dr. F. Buchthal presided at the next session, which was devoted to papers by Dr. J. M. Mitchison, on the mechanical properties of the cell surface, particularly in relation to cleavage ; Dr. E. Zeuthen on nuclear growth and respiration in dividing marine eggs, in the light of his recent experiments with the refined Cartesian diver technique; and Dr. C. Waymouth on the problems of maintenance and growth of tissues in vitro, in a variety of media of chemically defined composition.

The chair at the next day's meeting was taken by Dr. G. H. Bourne and Prof. P. Brandt Rehberg. The proceedings were opened by Drs. E. C. Slater and $\mathrm{K}$. W. Cleland, who discussed the respiratory and phosphorylative ability of heart muscle sarcosomes. Dr. S. R. Pelc and Dr. A. Howard followed with a communication on the effects of X-rays and neutrons on the synthesis of deoxyribonucleic acid in plant roots; Dr. H. Holter surveyed critically the existing methods by means of which different parts of the cell can be separated mechanically and used for studies on the localization of enzymes in the cytoplasm; Dr. R. Brown described the enzymatic changes which occur in the plant cell during growth. A much appreciated contribution was made by Prof. K. Linderstrøm-Lang, who analysed in a detailed manner the phenomena of diffusion and precipitation in Gomori's histochemical test for phosphatase. Dr. E. Hoff-Jørgensen spoke on the deoxyribonucleic acid content of some bacteria in relation to requirements for vitamin $B_{12}$.

Prof. J. N. Davidson took the chair on the last day of the meeting. Dr. H. Kalckar described recent experiments in which he used radioactive phosphorus for the demonstration of a pyrophosphorolysis of uridinediphosphoglucose to uridinetriphosphate and glucose-1-phosphate; Dr. R. Markham reported on some new structural characteristics of nucleic acids as revealed by the combined application of enzymic and chromatographic methods; Dr. J. A. V. Butler then spoke on the action of radiomimetic substances on nucleic acid; and Dr. C. Lutwak-Mann on the behaviour of nucleic acid in blood-forming tissues with special reference to X-ray injury.

The contributions were followed by stimulating comments and discussion, notably by Prof. C. H. Waddington, Drs. J. Ebling, J. A. Kitching, R. K. Morton and others. In conjunction with the conference three evening lectures were given. Dr. D. J. Bell reviewed the subject of "Transglycosidation : a Natural Method of Stored-energy Transfer" before the Danish Chemical Society; Dr. T. Mann spoke on "Sperm Survival and its Dependence on Metabolic Processes" to the Danish Biological Society; and Prof. J. Z. Young on "Experiments on Learning in the Octopus" to the Natural History Society.

The British party, who enjoyed initially the support of Dr. M. Swann and later of their efficient secretary, Dr. W. S. Bullough, were most cordially received and entertained by their Danish colleagues. Prof. H. V. Brønsted, Dr. H. Holter, Dr. H. Kalckar, Prof. K. Linderstrøm-Lang and Dr. E. Zeuthen spared no effort to assure for the conference the maximum of scientific and social success. A banquet at the ancient Munkekaelderen was honoured by the presence of the rector of the University of Copenhagen, Prof. H. M. Hansen.

\section{INTERNATIONAL UNION OF BIOLOGICAL SCIENCES}

\section{MEETING OF THE EXECUTIVE COMMITTEE}

$\mathrm{T}$

HE executive committee of the International Union of Biological Sciences met in London in the rooms of the Royal Society during March 4-5. This meeting was midway between the last General Assembly of the Union at Stockholm in 1950 and the next one to be held in the summer of 1953. Thirty members of the executive committee, from eight countries, were present, representing the nine Sections of the Union, namely, those of Biometry, Botany, Experimental Cytology, Embryology, Entomology, Genetics, Limnology, Microbiology and Zoology. Some of these Sections are identified with international bodies; thus the Section of Biometry is constituted by the Biometrical Society, the Section of Experimental Cytology by the Society of Cell Biology, the Section of Microbiology by the International Association of Microbiologists, and the SubSection of Zoological Nomenclature by the International Commission on Zoological Nomenclature. The executive committee expressed the desire that all Sections of the Union, some of which are already affiliated to the permanent committees of International Congresses, should as far as possible be identified with international organizations having 